\title{
Mercury concentrations in the goliath grouper of Belize: an anthropogenic stressor of concern
}

\author{
David C. Evers ${ }^{1, *}$, Rachel T. Graham ${ }^{2}$, Christopher R. Perkins ${ }^{3}$, Robert Michener ${ }^{4}$, \\ Tim Divoll ${ }^{1}$
}

\author{
${ }^{1}$ BioDiversity Research Institute, 19 Flaggy Meadow Road, Gorham, Maine 04038, USA \\ ${ }^{2}$ Ocean Giants, Marine Program, Wildlife Conservation Society, PO Box 76, Punta Gorda, Belize \\ ${ }^{3}$ Center for Environmental Sciences and Engineering, University of Connecticut, Storrs, Connecticut 06269-5210, USA \\ ${ }^{4}$ IRMS Laboratory, Boston University Stable Isotope Laboratory, Department of Biology, 5 Cummington St., Boston, \\ Massachusetts 02215, USA
}

\begin{abstract}
Global levels of available methylmercury (MeHg) in aquatic ecosystems have increased dramatically over the past century. Recent findings in temperate North America have shown that biological mercury $(\mathrm{Hg})$ hotspots exist, and these hotspots can be related to local emission and effluent sources. Life history traits of the goliath grouper Epinephelus itajara place it as a species at high risk of adverse effects from environmental $\mathrm{Hg}$ loads. Muscle $\mathrm{Hg}$ analyses for 57 goliath groupers sampled in southern Belize reveal that $40 \%$ exceed United States governmental advisory criteria for human health; all individual grouper exceeding these criteria were $>55 \mathrm{~cm}$ total length. People, particularly from coastal areas in southern Belize, commonly consume goliath grouper. The regular consumption of goliath grouper by sensitive groups of people, such as pregnant women, should be closely monitored, particularly in biological $\mathrm{Hg}$ hotspots. Stable isotope analysis for $\delta^{13} \mathrm{C}$ and $\delta^{15} \mathrm{~N}$ in goliath grouper indicates a broad prey base with a relatively high trophic status. Through biomagnification and bioaccumulation of $\mathrm{MeHg}$, older individuals are therefore at greatest risk of physiological impairment, particularly when performing complex and coordinated behaviors, such as those associated with spawning aggregations. Potential adverse effects of MeHg loads on goliath grouper, including predator avoidance, impaired growth rates, and lowered reproductive success, warrant investigation. This is particularly urgent for the critically endangered goliath grouper because of recent range-wide population declines, loss of spawning aggregations, and our findings, which present compelling evidence that tropical marine ecosystems are sensitive to $\mathrm{Hg}$ inputs.
\end{abstract}

KEY WORDS: Goliath grouper $\cdot$ Mercury $\cdot$ Belize $\cdot$ Stable isotopes $\cdot$ Human health $\cdot$ Conservation

\section{INTRODUCTION}

Mercury $(\mathrm{Hg})$ is a natural element which is redistributed at levels greater than historical patterns through the burning of fossil fuels and Hg-laden waste, industrial use, and activities such as artisanal gold mining. A principal concern with such elevated $\mathrm{Hg}$ in the environment is the potential for adverse effects on organisms. The toxic form, methylmercury ( $\mathrm{MeHg}$ ), is of particular concern because of its ability to readily biomagnify in food webs. Humans and certain fish and wildlife species may be at great risk from the effects of environmental $\mathrm{MeHg}$ loads through exposure at higher trophic levels of the food web (Mahaffey et al. 2004, Harris et al. 2007). Although the specific concentration of $\mathrm{Hg}$ in fish, and, ultimately, people, that poses a risk is not universally accepted, well established guidelines are in place; for example, the United States Environmental Protection Agency (US EPA) has published a human health advisory criterion for fish with muscle $\mathrm{Hg}$ concentrations of $0.30 \mu \mathrm{g} \mathrm{g}^{-1}$ wet weight (WW). Scientific evidence of harmful cardiovascular 
(Stern 2005), neurobehavioral (Weil et al. 2005), and neurodevelopmental (Mahaffey et al. 2004) effects from the consumption of fish with elevated MeHg concentrations is growing (Anderson 2008). In response to current environmental $\mathrm{Hg}$ loads in North America, Mergler et al. (2007, p. 8) concluded that to 'preserve human health, all efforts need to be made to reduce and eliminate sources of exposure.' A similar case can now be made for the health of fish based on an emerging list of recent laboratory and field studies demonstrating adverse effects from elevated $\mathrm{MeHg}$ body burdens (Hammerschmidt et al. 2002, Drevnick et al. 2006, 2008, Moran et al. 2007, Larose et al. 2008).

The Mesoamerican Reef is the largest barrier reef system in the western hemisphere and one of the top marine biodiversity sites in the world (Roberts et al. 2002). It is well known for its biologically diverse communities of corals, mangroves, and seagrasses that serve as rich nursery, breeding, and feeding grounds for many commercially and recreationally significant species. In Belize alone, at least 37 species of sharks and 13 species of grouper, including the Caribbean's endemic Nassau grouper Epinephelus striatus and critically endangered goliath grouper E. itajara, are found along this reef. However, many shark, grouper, and other fish species are rapidly declining in the Mesoamerican Reef because of unsustainable fishing pressures, habitat degradation, and other anthropogenic stressors (Sala et al. 2001, Mumby et al. 2004, Graham et al. 2009, this Theme Section).

We chose this area as a case study because of its global biological importance, conservation needs from increasing recreational and development pressures, and existing scientific infrastructure. Because little is known about MeHg cycling in marine tropical ecosystems in Central America, the template we create here for understanding the (1) distribution of $\mathrm{Hg}$ in estuarine and marine systems, (2) sources of anthropogenic $\mathrm{Hg}$, (3) availability to biota, (4) food web dynamics based on stable isotope analyses, and (5) impacts on human and ecological health, can be applied to other areas of the Caribbean. In the present study, we establish a preliminary baseline for $\mathrm{Hg}$ exposure in goliath grouper Epinephelus itajara in southern Belize to help characterize potential human and ecological health concerns in coastal marine ecosystems.

\section{MATERIALS AND METHODS}

Study area. The study area is associated with the Mesoamerican Reef in the Gulf of Honduras of southern Belize (Fig. 1), an embayment bordered by Guatemala and Honduras. Southern Belize encompasses coastal fluvial, estuarine, and mangrove eco- systems favoring young-of-the-year to subadults (up to Age 6), as well as nearshore and offshore seagrass, patch reef, and barrier reef sites that are the preferred habitat of adult goliath grouper (Bullock et al. 1992, Sadovy \& Eklund 1999). The present study focused on an embayment adjacent to Guatemala with over $4665 \mathrm{~km}^{2}$ of coastal grouper habitat delineated by the Sarstoon River, which separates Belize from Guatemala, east to the Sapodilla Cayes on the Belize Barrier Reef and north of Tobacco Caye on the barrier reef to the mouth of the Sittee River located near the coastal village of Riversdale.

Field sample collection. Goliath groupers were sampled and measured at the Punta Gorda fish market in Belize from January 2006 to December 2007 (Graham et al. 2009). Biopsies of muscle tissue from the dorsal and pectoral musculature were removed from goliath grouper between March 2006 and November 2007. Although specific locations within our study were not identified for individuals, we are confident that fish sampled at the Punta Gorda market represent our defined study area based on fisher interviews confirming fishing locations. Samples of $10 \times 40 \mathrm{~mm}$ of muscle tissue were cataloged, stored, and frozen in $10 \mathrm{cc}$

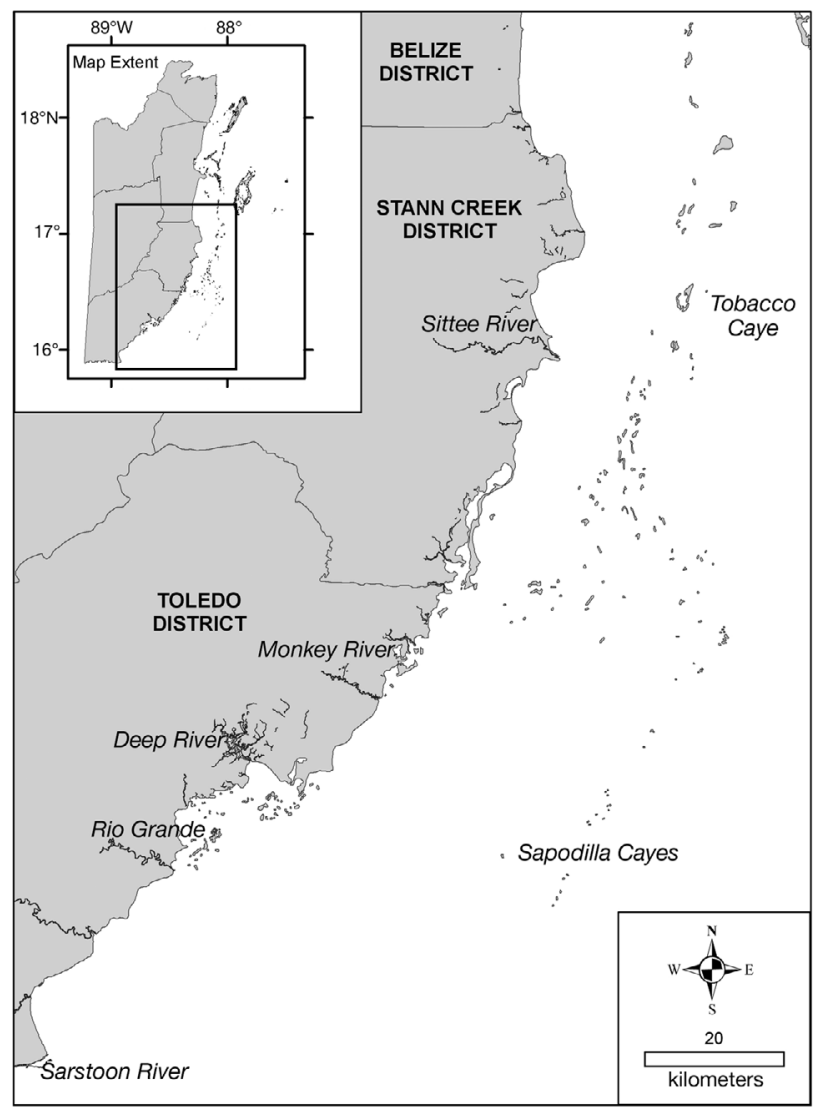

Fig. 1. Study area (rectangle in inset), showing 3 coastal districts of Belize 
transport tubes and shipped to the USA. Biopsies of muscle tissue from the base of a fin (Gremillion et al. 2005) and other areas of the body (Peterson et al. 2004) strongly correlate with muscle tissue most commonly consumed by people and are not significantly different from traditional methods of sampling and analysis (Baker et al. 2004). Total length (TL) and weight of freshly caught individuals were collected. Lengthweight relationships were determined for goliath grouper landed in Punta Gorda, southern Belize from December 2005 to December 2007 (n = 890) (Graham et al. 2009).

Mercury analysis. All samples were submitted to the Center for Environmental Sciences and Engineering at the University of Connecticut. Each grouper muscle sample was thawed, a $5.0 \mathrm{~g}$ piece was removed and homogenized, and a $0.5 \mathrm{~g}$ subsample was placed into a $50 \mathrm{ml}$ hot block tube. Four ml of concentrated sulfuric acid and $1 \mathrm{ml}$ of concentrated nitric acid were added to each tube and placed in the hot block at $58^{\circ} \mathrm{C}$ for $60 \mathrm{~min}$. The tubes were removed from the hot block, cooled to room temperature and $5 \mathrm{ml}$ of potassium permanganate $\left(\mathrm{KMnO}_{4}\right)$ solution was added. If the sample did not maintain a standard color, more $\mathrm{KMnO}_{4}$ was added in increments of $2 \mathrm{ml}$ until a standard color was maintained. Eight $\mathrm{ml}$ of potassium persulfate $\left(\mathrm{K}_{2} \mathrm{~S}_{2} \mathrm{O}_{8}\right)$ was added to each tube and the samples were allowed to stand overnight at room temperature. Two $\mathrm{ml}$ of hydroxylamine hydrochloride $\left(\mathrm{NH}_{2} \mathrm{OH}-\mathrm{HCl}\right)$ was added to each tube and then brought up to a final volume of $50 \mathrm{ml}$ using deionized water. All grouper samples were subsequently analyzed on a Perkin Elmer flow injection mercury system (FIMS) cold vapor atomic absorption spectrometer using standard protocols at the University of Connecticut. Quality assurance procedures were employed, including analysis of duplicate samples, method blanks, post-digestion spiked samples, laboratory control samples, and standard reference materials (DOLT-3, National Research Council Canada). Instrument response was evaluated initially, every 20 samples, and at the end of an analytical run using a calibration verification standard and blank. Percent moisture averaged $82 \pm 4 \%$ on a subset of 15 samples; this is indicative of typical moisture content for fish muscle tissue and does not confound interpretation of $\mathrm{Hg}$ concentrations.

Mercury concentrations of concern. Human health advisory levels for the consumption of fish vary according to different governmental bodies. The US EPA uses a criterion of $0.30 \mathrm{\mu g} \mathrm{g}^{-1} \mathrm{WW}$, while the World Health Organization (WHO) uses an advisory threshold of $0.50 \mu \mathrm{g} \mathrm{g}^{-1} \mathrm{WW}$, except for predatory fish, which have a $1.00 \mathrm{~g} \mathrm{~g} \mathrm{~g}^{-1} \mathrm{WW}$ threshold (WHO 2007). We used the latter WHO threshold for the predatory goliath grouper.
Stable isotope analysis. Samples were also shipped to the Boston University Stable Isotope Laboratory for analysis of $\delta^{13} \mathrm{C}$ and $\delta^{15} \mathrm{~N}$. Samples were analyzed using automated continuous-flow isotope ratio mass spectrometry (Michener \& Lajtha 2007). All specimens were subsampled and oven-dried at $60^{\circ} \mathrm{C}$ for $24 \mathrm{~h}$. They were then powdered using a mortar and pestle. The samples were combusted in a EuroVector Euro EA elemental analyzer to provide $\mathrm{C}: \mathrm{N}$ ratios. The combustion gases $\left(\mathrm{N}_{2}\right.$ and $\left.\mathrm{CO}_{2}\right)$ were separated on a chromatographic column, passed through a reference gas box, and introduced into the GV Instruments IsoPrime isotope ratio mass spectrometer; water was removed using a magnesium perchlorate water trap. Ratios of ${ }^{13} \mathrm{C} /{ }^{12} \mathrm{C}$ and ${ }^{15} \mathrm{~N} /{ }^{14} \mathrm{~N}$ were expressed as the relative per mil (\%o) difference between the samples and international standards (Vienna PeeDee Belemnite [VPDB] carbonate and $\mathrm{N}_{2}$ in air):

$$
\%=\left(R_{\text {sample }} / R_{\text {standard }}-1\right) \times 1000(\%)
$$

where $X={ }^{13} \mathrm{C}$ or ${ }^{15} \mathrm{~N}$ and $R={ }^{13} \mathrm{C} /{ }^{12} \mathrm{C}$ or ${ }^{15} \mathrm{~N} /{ }^{14} \mathrm{~N}$.

The sample isotope ratio was compared to a secondary gas standard, whose isotope ratio was calibrated to international standards. All international standards were obtained from the National Bureau of Standards (NBS) in Gaithersburg, Maryland. For ${ }^{13} \mathrm{C}_{\text {VPDB }}$ the gas was calibrated against NBS 20 (Solenhofen limestone). For ${ }^{15} \mathrm{~N}_{\text {air }}$ the gas was calibrated against atmospheric $\mathrm{N}_{2}$ and International Atomic Energy Agency (IAEA) standards N-1, N-2, and N-3 (all are ammonium sulfate standards). In addition to carbon and nitrogen isotopes from the same sample, continuous flow also reported \% $\mathrm{C}$ and \% $\mathrm{N}$ data.

Statistical analysis. Mercury concentrations, length-weight relationships, and stable isotope ratios were normally distributed and met homoscedasticity assumptions. An unequal variance $t$-test was used to determine significant differences at $\alpha=0.05$; this test is considered equivalent to a Student's $t$-test in its ability to control for Type 1 and Type 2 errors, and superior to the Mann-Whitney $U$-test assuming the underlying sample size exceeds 30 and is normally distributed (Ruxton 2006). In order to compare $\mathrm{Hg}$ concentrations in a standardized way for individual fish representing a range of sizes, length adjustments were simply made by dividing $\mathrm{Hg}$ concentration by $\mathrm{TL} \times 100$.

\section{RESULTS}

A total of 57 goliath groupers from southern Belize were sampled for $\mathrm{Hg}$ concentrations and $\delta^{13} \mathrm{C}$ and $\delta^{15} \mathrm{~N}$ isotope values in 2006 and 2007. Of these, $40 \%$ exceeded the US EPA criterion (Fig. 2). 


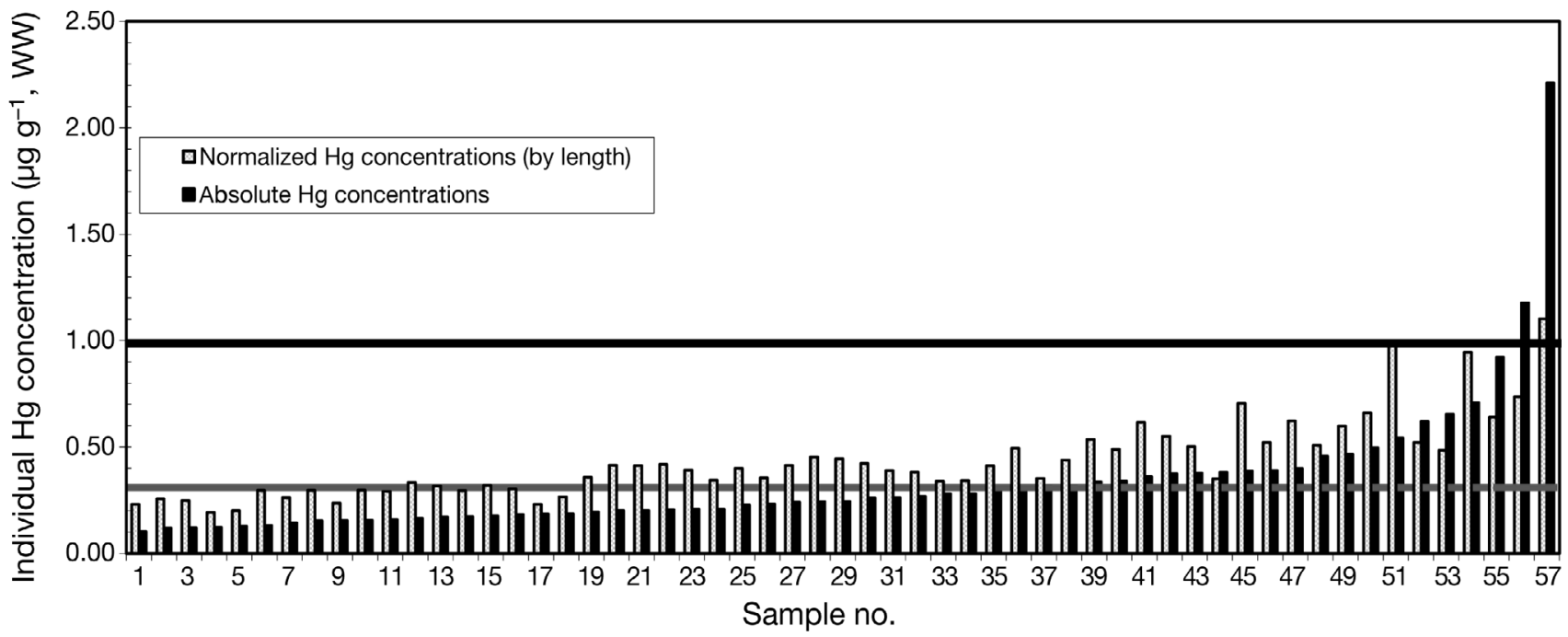

Fig. 2. Epinephelus itajara. Distribution of muscle $\mathrm{Hg}$ concentrations ( $\mu \mathrm{g} \mathrm{g}^{-1}$ wet weight [WW]) for goliath grouper (n = 57) in Belize. A total of $40 \%$ of the groupers sampled were above the US Environmental Protection Agency human health standard for Hg of $0.30 \mu \mathrm{g} \mathrm{g}^{-1} \mathrm{WW}$ (gray line). The World Health Organization human consumption advisory level is $1.0 \mu \mathrm{g} \mathrm{g} \mathrm{g}^{-1} \mathrm{WW}$ (black line)

The size distribution of groupers was skewed to smaller and younger individuals. There was a highly significant length-weight relationship $\left(\mathrm{n}=890, \mathrm{r}^{2}=\right.$ $0.98, \mathrm{p}<0.001)$. Comparison of length-normalized and absolute Hg concentrations between smaller mangrove-dependent individuals $(\mathrm{TL}<110 \mathrm{~cm})$ and larger offshore dwelling individuals $(\mathrm{TL}>110 \mathrm{~cm}$ ) indicated significantly higher $\mathrm{Hg}$ concentrations in the offshore individuals for normalized ( $t=2.77, \mathrm{df}=4, \mathrm{p}=0.05$ ) and absolute $(t=2.92, \mathrm{df}=4, \mathrm{p}=0.04)$ concentrations (Fig. 3).

Unexpectedly, the $\delta^{15} \mathrm{~N}$ values for large, reef-dependent grouper were not significantly different from those for smaller, mangrove-dependent individuals $(t=$ $0.71, \mathrm{df}=7, \mathrm{p}=0.50)$; however, these same groups differed significantly in $\delta^{13} \mathrm{C}$ values (Fig. 4).

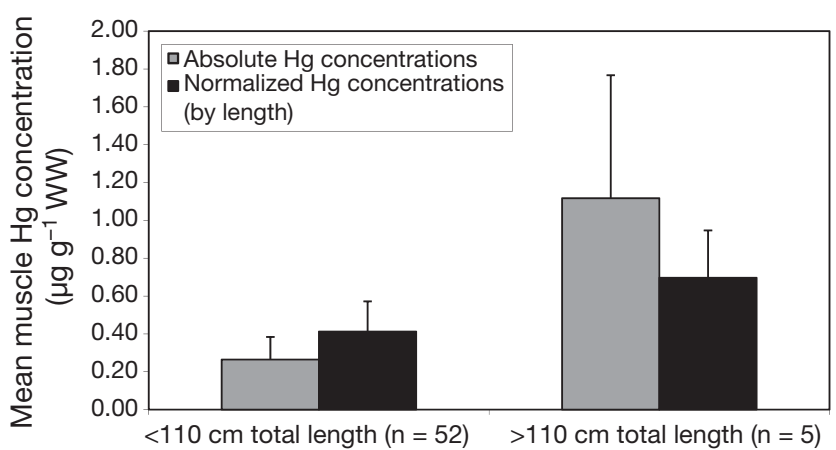

Fig. 3. Epinephelus itajara. Comparison of subadult and breeding adult goliath grouper $\mathrm{Hg}$ concentrations. Age class is designated by total length (TL), where individuals of TL < $110 \mathrm{~cm}$ are subadults and those of TL $>110 \mathrm{~cm}$ are adults

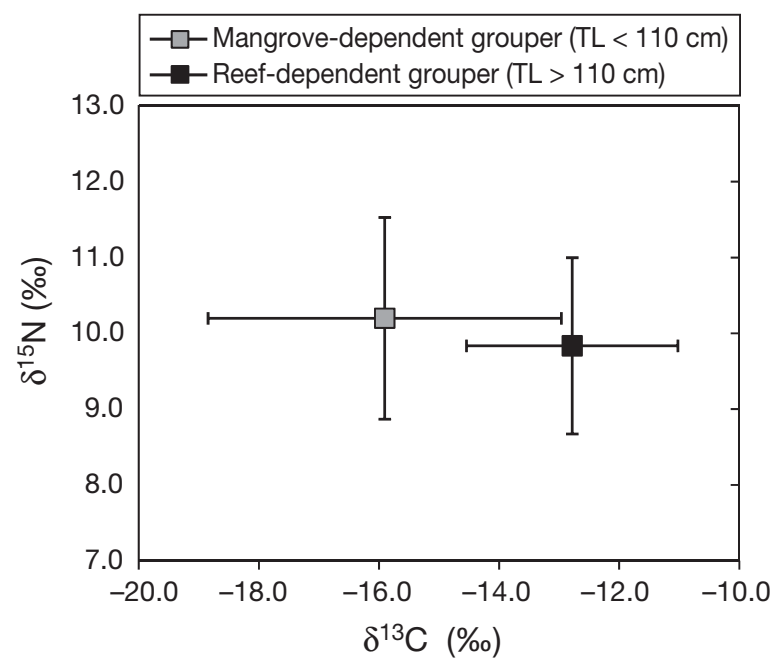

Fig. 4. Epinephelus itajara. Stable isotope ratios of $\delta^{13} \mathrm{C}$ and $\delta^{15} \mathrm{~N}$ and their relationship with 2 size classes. Grouper inhabit mangrove habitats up to Age 6 or approximately $<110 \mathrm{~cm}$ in total length (TL) and move to reef areas thereafter $(\mathrm{TL}>110 \mathrm{~cm})$

\section{DISCUSSION}

Although global atmospheric deposition models indicate relatively low rates of $\mathrm{Hg}$ input into Central America (Mason et al. 1994), there is evidence that tropical marine ecosystems are sensitive to Hg input, suggesting more efficient bioaccumulation than in temperate marine ecosystems. Guzman \& Garcia (2002) characterized Hg concentrations in coral from reefs in Panama and Costa Rica for areas without 
known, elevated point sources. They suggested deleterious $\mathrm{Hg}$ effects with land use origins that included legacy gold mining, erosion following deforestation, and recent shoreline development. While fish $\mathrm{Hg}$ concentrations for nearshore waters of Belize are not known, recent studies in the northern Gulf of Mexico provide a context suitable for comparison of marine fish $\mathrm{Hg}$ concentrations within a similar trophic level (Bank et al. 2007, Lewis \& Chancy 2008).

The goliath grouper is a large, long-lived marine fish. Individuals may reach $2.55 \mathrm{~m}$ and $308 \mathrm{~kg}$, and are known to live up to $37 \mathrm{yr}$ (Heemstra 1991, Sadovy \& Eklund 1999). Although marine fish with these life history characteristics are well recognized for an ability to bioaccumulate $\mathrm{MeHg}$, and include sharks (GarciaHernandez et al. 2007), tuna (Storelli et al. 2002), and swordfish (Storelli \& Marcotrigiano 2000), Hg concentrations in goliath grouper are poorly documented (Sadovy \& Eklund 1999). Our analysis provides the first evaluation of $\mathrm{Hg}$ for the goliath grouper and highlights potential concerns regarding $\mathrm{Hg}$ and human and ecological health along the Mesoamerican Barrier Reef.

\section{Human health concerns}

In the present study, we demonstrate that Hg concentrations in goliath groupers regularly exceed those reported for the Gulf of Mexico as well as the US EPA human health criterion. Mercury concentrations (absolute and normalized values) are highest for the adult grouper inhabiting offshore cayes and banks. Smaller, coastal, and estuarine mangrove-dependent individuals begin exceeding the US EPA criterion of $0.30 \mu \mathrm{g} \mathrm{g}^{-1} \mathrm{WW}$ at $55 \mathrm{~cm}$ in length. All individuals over $83 \mathrm{~cm}$ in length had $\mathrm{Hg}$ concentrations greater than the US EPA criterion. Comparisons of length-normalized $\mathrm{Hg}$ concentrations in red snappers Lutjanus campechanus from within the Gulf of Mexico (Bank et al. 2007) indicate that mean Hg concentrations in similar-sized goliath grouper inhabiting southern Belize mangroves are approximately $40 \%$ higher. While red snappers may occupy, on average, a higher trophic position than groupers $\left(\delta^{15} \mathrm{~N}\right.$ of 14.7 vs. 10.2 , respectively), specific comparisons are difficult because we lack isotopic baselines needed for appropriate interpretation (Post 2002).

The amount and frequency of fish consumed, their corresponding $\mathrm{Hg}$ body burdens, and the sensitivity of a person to $\mathrm{MeHg}$ toxicity are factors that determine human health risk (Mahaffey et al. 2004, Mergler et al. 2007). Marine fish and shellfish Hg concentrations are poorly documented for coastal areas of Central America; therefore, characterizing $\mathrm{Hg}$ exposure risk to Belizeans is difficult. Mercury concentrations in the blood of American women are well described by the US National Health and Nutrition Examination Survey (NHANES) (Mahaffey et al. 2004). Mean Hg concentrations of goliath grouper $\left(0.34 \mu^{-1} \mathrm{~g}^{-1}\right.$, range $=0.10$ to $2.21 \mathrm{\mu g} \mathrm{g}^{-1}$ ) exceed $80 \%$ of the mean Hg concentrations of marine fish and shellfish species that form the basis of NHANES studies (Mahaffey et al. 2004). In 2000, Belizean fish consumption was estimated annually at $15 \mathrm{~kg}$ per person (WRI 2003). These consumption rates exceed the annual $4.3 \mathrm{~kg}$ per person consumption used by the US EPA (for women between the ages of 15 and 44). Assuming that Belizeans consume fish with average $\mathrm{Hg}$ concentrations greater than those consumed in the USA, we speculate that at least onethird of Belizean women could be ingesting harmful $\mathrm{Hg}$ concentrations from diets of local fish.

The Global Mercury Assessment Program of UNEP recently convened Caribbean countries to collectively evaluate environmental $\mathrm{Hg}$ loads for the region (UNEP 2005). Their findings highlight the paucity of available data, yet strong recommendations were prepared to better understand potential threats from environmental $\mathrm{Hg}$ loads on ecological and human health. Our analysis strengthens the need for a more thorough evaluation of the risk that marine fish and shellfish $\mathrm{Hg}$ concentrations pose to people in coastal communities in Belize and neighboring countries.

\section{Ecological health concerns}

Environmental $\mathrm{Hg}$ loads and their potential effects on fish are poorly known in tropical marine ecosystems of the Caribbean, including the coastline of Belize (Lacher \& Goldstein 1997, UNEP 2005). The few Caribbean studies describing $\mathrm{Hg}$ concentrations in marine fish were generally triggered by known point sources such as chlor-alkali plants in Columbia (Olivero-Verbel et al. 2008) and gold mining activities (Olivero et al. 1997, Mol et al. 2001). One coastal study, near Cumaná in Venezuela, documented mean Hg concentrations for 17 species of fish at $0.10 \pm 0.04 \mu \mathrm{g}$ $\mathrm{g}^{-1} \mathrm{WW}$ (SD), with a maximum of $0.33 \mu \mathrm{g} \mathrm{g}^{-1} \mathrm{WW}$ for a $2000 \mathrm{~g}$ tajali Trichiurus lepturus, in an area without known local anthropogenic Hg sources (Shrestha et al. 1988).

The highly elevated concentrations of $\mathrm{Hg}$ found in goliath grouper from the present study are unexpected, given the lack of known proximal point sources. While the northern lagoons of Belize appear to have relatively low MeHg availability to high tropic level predators such as the Morelet's crocodile Crocodylus moreletii (Rainwater et al. 2002), southern Belize mangrove and coral reef habitats appear to be either sensitive to $\mathrm{Hg}$ input or affected by large undescribed point sources. 
Spatial heterogeneity of MeHg availability or biological $\mathrm{Hg}$ hotspots is an established phenomenon in temperate freshwater aquatic ecosystems (Evers et al. 2007). Mechanisms for such spatial gradients in tropical marine ecosystems remain relatively undefined, although marine-oriented biogeochemical cycling models for MeHg are being developed (Fitzgerald et al. 2007) and could contribute to greater understanding.

Considering the life history traits of groupers, the general lack of scientific investigation into the ability of goliath grouper and other grouper species to biomagnify and bioaccumulate $\mathrm{MeHg}$ is surprising. For example, recent governmental evaluations of continental US goliath grouper populations did not identify environmental $\mathrm{Hg}$ loads as a known or potential threat (NMFS 2006), even though the core of the grouper's range in Florida has well described environmental Hg burdens in estuarine and marine fish (Kannan et al. 1998, Adams \& McMichael 1999, Strom \& Graves 2001)

Mercury concentrations in some goliath grouper individuals are consistent with documented adverse effects in other fish species, including predator evasion, spawning success, and body weight (Friedmann et al. 1996). Little is known about sublethal effects of $\mathrm{MeHg}$ on marine fish. However, investigations involving a marine species, the Atlantic croaker Micropogonias undulatus, demonstrate that consumption of MeHg-contaminated food of $0.10 \mu \mathrm{g} \mathrm{g}^{-1} \mathrm{WW} \mathrm{d}^{-1}$ by adults resulted in maternal body burdens of $\mathrm{MeHg}$ transferred to larvae as well as to negatively impacted survival skills such as predator evasion behavior (Alvarez et al. 2006), an effect from MeHg that is also found in freshwater fish (Webber \& Haines 2003). Such sublethal effects can have significant impacts on predation rates of larvae (Murphy et al. 2008). In neighboring Guatemala, mean Hg concentrations in various relatively small fish species and even saltwater shrimp Carcinus moenas were equal to or exceeded $0.10 \mu \mathrm{g}$ $\mathrm{g}^{-1}$ WW in the Gulf of Honduras community of Puerto Barrios, Guatemala (Ramos et al. 1979).

The effects of MeHg on spawning success have been demonstrated in laboratory-dosing studies of freshwater fish (Hammerschmidt et al. 2002, Drevnick et al. 2008) at $\mathrm{Hg}$ concentrations regularly found in goliath grouper of southern Belize. Goliath grouper reproduce in spawning aggregations that may include 10 s to over 100 individuals (Sadovy \& Eklund 1999). The potential negative effects of environmental pollutants on complex fish behaviors (Scott \& Sloman 2004), coupled with our findings of a strong relationship between increasing muscle $\mathrm{Hg}$ and size, suggest that the reproductive potential for large groupers may be compromised.

Ecological redundancy and associated resistance to ecological changes from human disturbances in marine ecosystems varies geographically, and poten- tial recovery to former levels of ecosystem functioning is complex and not well understood, particularly for tropical nearshore areas (Palumbi et al. 2008). The goliath grouper was formerly common in coastal Belize until the 1980s (Graham et al. 2009). The loss of this apex predator could create changes in community function and structure similar to the dramatic changes to fisheries which occurred when shark populations were severely reduced (Myers et al. 2007). In response, active investigations to determine the source of coastal environmental Hg loads in Belize and patterns of spatial Hg gradients are necessary. In the continental US (primarily Florida), goliath grouper populations have benefited from protective measures including a complete ban on fishing (NMFS 2006). Conservation and, ultimately, recovery of Belizean goliath grouper populations are more tenuous than in Florida, especially if anthropogenic stressors such as greater environmental Hg loads should impede growth rate, reproductive success, and overall fitness.

We recommend identification of point sources and standardized Hg monitoring programs to evaluate spatiotemporal trends and potential risk to human and ecological health. Descriptions of Hg monitoring programs developed for temperate North American landscapes (Harris et al. 2007) including estuarine and marine ecosystems (Evers et al. in press) are available and transferable to tropical ecosystems. Such standardized monitoring efforts will serve as important benchmarks for evaluating adverse effects of $\mathrm{Hg}$ in other grouper species and help establish best management practices for declining grouper populations.

Acknowledgements. We thank the Munson Foundation, the Summit Foundation, and the Henry Foundation for funding support. We thank the Departments of Fisheries and Forestry for extending the permits enabling this research to take place as well as the Toledo Institute for Development and Environment, co-managers of the Port Honduras Marine Reserve and Payne's Creek National Park. We thank J. Stockbridge, Marine Conservation Project Manager for The Nature Conservancy in Belize, for GIS layers to develop our study area map. We thank Dan Castellanos for conducting much of the field sampling. Finally we are grateful to J. Cab for coordinating landings data in the Punta Gorda Market, to R. Polonio for taking and cataloging samples, and to the fishers of Punta Gorda for allowing us to sample their goliath grouper.

\section{LITERATURE CITED}

Adams DH, McMichael RH Jr (1999) Mercury levels in four species of sharks from the Atlantic coast of Florida. Fish Bull 97:372-379

- Alvarez MC, Murphy CA, Rose KA, McCarthy ID, Fulman LA (2006) Maternal body burdens of methylmercury impair survival skills of offspring in Atlantic croaker (Micropognias undulates). Aquat Toxicol 80:329-337 
Anderson HA (2008) Eighth international conference on mercury as a global pollutant (ICMGP): human health and exposure to methylmercury. Environ Res 107:1-3

Baker RF, Blanchfield PJ, Paterson MJ, Flett RJ, Wesson L (2004) Evaluation of nonlethal methods for the analysis of mercury in fish tissue. Trans Am Fish Soc 133:568-576

Bank MS, Chesney E, Shine JP, Maage A, Senn DB (2007) Mercury bioaccumulation and trophic transfer in sympatric snapper species from the Gulf of Mexico. Ecol Appl 17:2100-2110

Bullock LH, Murphy MD, Godcharles MF, Mitchell ME (1992) Age, growth and reproduction of jewfish, Epinephelus itajara, in the eastern Gulf of Mexico. Fish Bull 90:243-249

> Drevnick PE, Sandheinrich MB, Oris JT (2006) Increased ovarian follicular apoptosis in fathead minnows (Pimephales promelas) exposed to dietary methylmercury. Aquat Toxicol 79:49-54

Drevnick PE, Roberts AP, Otter RR, Hammerschmidt CR, Klaper R, Oris JT (2008) Mercury toxicity in livers of northern pike (Esox lucius) from Isle Royale, USA. Comp Biochem Physiol C 147:331-338

Evers DC, Han YJ, Driscoll CT, Kamman NC and others (2007) Identification and evaluation of biological hotspots of mercury in the northeastern US and eastern Canada. Bioscience 57:29-43

Evers DC Mason RP, Kamman NC, Chen CY and others (in press) An integrated mercury monitoring program for temperate estuarine and marine ecosystems on the North American Atlantic coast. EcoHealth

> Fitzgerald WF, Lamborg CH, Hammerschmidt CR (2007) Marine biogeochemical cycling of mercury. Chem Rev 107:641-662

Friedmann AS, Watzin MC, Brinck-Johnsen T, Leiter JC (1996) Low levels of dietary methylmercury inhibit growth and gonadal development in juvenile walleye (Stizostedion vitreum). Aquat Toxicol 35:265-278

> Garcia-Hernandez J, Cadena-Cardenas L, BetancourtLozano LM, Garcia-de-la-Parra LM, Garcia-Rico L, Marquez-Farias F (2007) Total mercury content found in edible tissues of top predator fish from the Gulf of California, Mexico. Toxicol Environ Chem 89:507-522

Graham RT, Rodes KL, Castellanos D (2009) Characterization of the goliath grouper Epinephelus itajara Lichtenstein (1822), fishery of southern Belize for conservation planning. Endangn Species Res 7:195-204

> Gremillion PT, Cizdziel JV, Cody NR (2005) Caudal fin mercury as a non-lethal predictor of fish-muscle mercury. Environ Chem 2:96-99

Guzman HM, Garcia EM (2002) Mercury levels in coral reefs along the Caribbean coast of Central America. Mar Pollut Bull 44:1415-1420

> Hammerschmidt CR, Sandheinrich MB, Wiener JG, Rada RG (2002) Effects of dietary methylmercury on reproduction of fathead minnows. Environ Sci Technol 36:877-883

Harris R, Krabbenhoft DP, Mason R, Murray MW, Reash R, Saltman T (2007) Ecosystem response to mercury contamination: indicators of change. CRC Press, Boca Raton, FL

Heemstra PC (1991) A taxonomic revision of the eastern Atlantic groupers (Pisces: Serranidae). Bol Mus Munic Funchal 43:5-7

Kannan K, Smith RG Jr, Lee RF, Windom HL, Heitmuller PT, Macauley JM, Summers JK (1998) Distribution of total mercury and methyl mercury in water, sediment, and fish from South Florida estuaries. Arch Environ Contam Toxicol 34:109-118

> Lacher TE Jr, Goldstein MI (1997) Tropical ecotoxicology: status and needs. Environ Toxicol Chem 16:100-111
Larose C, Canuel R, Lucotte M, Di Giulio RT (2008) Toxicological effects of methylmercury on walleye (Sander vitreus) and perch (Perca flavescens) from lakes of the boreal forest. Comp Biochem Physiol C 147:139-149

Lewis M, Chancy C (2008) A summary of total mercury concentrations in flora and fauna near common contaminant sources in the Gulf of Mexico. Chemosphere 70: 2016-2024

> Mahaffey KR, Clickner RP, Bodurow CC (2004) Blood organic mercury and dietary mercury intake: National Health and Nutrition Examination Survey, 1999 and 2000. Environ Health Perspect 112:562-570

> Mason RP, Fitzgerald WF, Morel FM (1994) The biogeochemical cycling of elemental mercury: anthropogenic influences. Geochim Cosmochim Acta 58:3191-3198

> Mergler D, Anderson HA, Chan LHM, Mahaffey KR, Murray M, Sakamoto M, Stern AH (2007) Methylmercury exposure and health effects in humans: a worldwide concern. Ambio 36:3-11

Michener R, Lajtha K (eds) (2007) Stable isotopes in ecology and environmental science, 2nd edn. Wiley-Blackwell Publishing, Hoboken, NJ

Mol JH, Ramlal JS, Lietar C, Verloo M (2001) Mercury contamination in freshwater, estuarine and marine fishes in relation to small-scale gold mining in Suriname, South America. Environ Res 86:183-197

Moran PW, Aluru N, Black RW, Vijayan MM (2007) Tissue contaminants and associated transcriptional response in trout liver from high elevation lakes of Washington. Environ Sci Technol 41:6591-6597

Mumby PJ, Edwards AJ, Arias-Gonzalez JE, Lindeman KC and others (2004) Mangroves enhance the biomass of coral reef fish communities in the Caribbean. Nature 427:533-536

Murphy CA, Rose KA, Alvarez MC, Fulman LA (2008) Modeling larval fish behavior: scaling the sublethal effects of methylmercury to population-relevant endpoints. Aquat Toxicol 86:470-484

> Myers RA, Baum JK, Shepherd TD, Powers SP, Peterson CH (2007) Cascading effects of the loss of apex predatory sharks from a coastal ocean. Science 315:1846-1849

NMFS (National Marine Fisheries Service) (2006) Status report on the continental United States distinct population segment of the goliath grouper (Epinephelus itajara). NMFS, Southeast Regional Office, St. Petersburg, FL

Olivero J, Navas V, Perez A, Solano B, Acosta I, Arguello E, Salas R (1997) Mercury levels in muscle of some fish species from the Dique Channel, Colombia. Bull Environ Contam Toxicol 58:865-870

Olivero-Verbel J, Johnson-Restrepo B, Baldiris-Avila R, Güette-Fernández J, Magallanes-Carreazo E, VanegasRamírez L, Kunihiko N (2008) Human and crab exposure to mercury in the Caribbean coastal shoreline of Colombia: impact from an abandoned chlor-alkali plant. Environ Int 34:476-482

Palumbi SR, McLeod KL, Grunbaum D (2008) Ecosystems in action: lessons from marine ecology about recovery, resistance, and reversibility. Bioscience 58:33-42

Peterson SA, Van Sickle J, Hughes RM, Schacher JA, Echols SF (2004) A biopsy procedure for determining filet and predicting whole-fish mercury concentration. Arch Environ Contam Toxicol 48:99-107

Post DM (2002) Using stable isotopes to estimate trophic position: models, methods, and assumptions. Ecology 83: 703-718

Rainwater TR, Adair BM, Platt SG, Anderson TA, Cobb GP, McMurry ST (2002) Mercury in Morelet's crocodile eggs 
from northern Belize. Arch Environ Contam Toxicol 42:319-324

Ramos A, de Campos M, Olszyna-Marzys AE (1979) Mercury contamination of fish in Guatemala. Bull Environ Contam Toxicol 22:488-493

Roberts CM, McClean CJ, Veron JEN, Hawkins JP and others (2002) Marine biodiversity hotspots and conservation priorities for tropical reefs. Science 295:1280-1284

Ruxton GD (2006) The unequal variance $t$-test is an underused alternative to Student's $t$-test and the Mann-Whitney $U$ test. Behav Ecol 17:688-690

Sadovy Y, Eklund AM (1999) Synopsis of biological data on the Nassau grouper, Epinephelus striatus (Bloch, 1792), and the jewfish, E. itajara (Lichtenstein, 1822). NOAA Tech Rep NMFS 146, US Dept Commerce, Seattle, WA

Sala E, Ballesteros E, Starr RM (2001) Rapid decline of Nassau grouper spawning aggregations in Belize: fishery management and conservation needs. Fisheries 26:23-30

Scott GR, Sloman KA (2004) The effects of environmental pollutants on complex fish behaviour: integrating behavioural and physiological indicators of toxicity. Aquat Toxicol 68:369-392

Shrestha KP, Noguera R, Chopite J, Sosa P (1988) Mercury content of some marine fish from the southern Caribbean Sea. Sci Total Environ 73:181-187

Stern AH (2005) A review of the studies of the cardiovascular health effects of methylmercury with consideration of their

Editorial responsibility: Kevin Rhodes,

Hilo, Hawaii, USA suitability for risk assessment. Environ Res 98: 133-142

Storelli MM, Marcotrigiano GO (2000) Fish for human consumption: risk of contamination by mercury. Food Addit Contam 17:1007-1011

Storelli MM, Stuffler RG, Marcotrigiano GO (2002) Total and methylmercury residues in tuna-fish from the Mediterranean Sea. Food Addit Contam 19:715-720

Strom DG, Graves GA (2001) A comparison of mercury in estuarine fish between Florida Bay and the Indian River Lagoon, Florida, USA. Estuaries 24:597-609

UNEP (United Nations Environment Programme) (2005) Regional awareness-raising workshop on mercury pollution: a global problem that needs to be addressed. UNEP Chemicals, Geneva

Webber HM, Haines TA (2003) Mercury effects on predator avoidance behavior of a forage fish, golden shiner (Notemigonus crysoleucas). Environ Toxicol Chem 22:1556-1561

> Weil M, Bressler J, Parsons P, Bolla K, Glass T, Schwartz B (2005) Blood mercury levels and neurobehavioral function. J Am Med Assoc 293:1875-1882

WHO (World Health Organization) (2007) CODEX general standard for contaminants and toxins in foods. CODEX STAN 193-1995, Rev.3-2007, WHO, Geneva

WRI (World Resources Institute) (2003) Coastal and marine ecosystems - Belize. Earth Trends Country Profiles, available at http://earthtrends.wri.org/pdf_library/country_ profiles/coa_cou_084.pdf

Submitted: March 15, 2008; Accepted: October 3, 2008 Proofs received from author(s): January 28, 2009 